\title{
Gender differences in the response of CD-1 mouse bone to parathyroid hormone: potential role of IGF-I
}

\author{
Yongmei Wang, Takeshi Sakata, Hashem Z Elalieh, \\ Scott J Munson, Andrew Burghardt' ${ }^{1}$, Sharmila Majumdar ${ }^{1}$, \\ Bernard P Halloran and Daniel D Bikle
}

Department of Medicine, Endocrine Unit, Veterans Affairs Medical Center, University of California, San Francisco, California 94117-1080, USA

${ }^{1}$ Department of Radiology, University of California, San Francisco, California 94117-1080, USA

(Requests for offprints should be addressed to D D Bikle; Email: daniel.bikle@ucsf.edu)

\begin{abstract}
Parathyroid hormone (PTH) exerts both catabolic and anabolic actions on bone. Studies on the skeletal effects of PTH have seldom considered the effects of gender. Our study was designed to determine whether the response of mouse bone to PTH differed according to sex. As a first step, we analyzed gender differences with respect to bone mass and structural properties of 4 month old PTH treated $(80 \mu \mathrm{g} / \mathrm{kg}$ per day for 2 weeks) male and female CD-1 mice. PTH significantly increased fat free weight/body weight, periosteal bone formation rate, mineral apposition rate, and endosteal single labeling surface, while significantly decreasing medullary area in male mice compared with vehicle treated controls, but induced no significant changes in female mice. We then analyzed the gender differences in bone marrow stromal cells (BMSC) isolated from 4 month old male and female CD-1 mice following
\end{abstract}

treatment with PTH $(80 \mu \mathrm{g} / \mathrm{kg}$ per day for 2 weeks). PTH significantly increased the osteogenic colony number and the alkaline phosphatase (ALP) activity (ALP/cell) by day 14 in cultures of BMSCs from male and female mice. PTH also increased the mRNA level of receptor activator of nuclear factor $\mathrm{KB}$ ligand in the bone tissue (marrow removed) of both females and males. However, PTH increased the mRNA levels of IGF-I and IGF-IR only in the bones of male mice. Our results indicate that on balance a 2-weeks course of PTH is anabolic on cortical bone in this mouse strain. These effects are more evident in the male mouse. These differences between male and female mice may reflect the greater response to PTH of IGF-I and IGF-IR gene expression in males enhancing the anabolic effect on cortical bone.

Journal of Endocrinology (2006) 189, 279-287

\section{Introduction}

Parathyroid hormone $(\mathrm{PTH})$ is a major regulator of calcium and phosphate homeostasis. It has complex effects on bone. When given intermittently, PTH increases bone mass and strength (Alexander et al. 2001, Dempster et al. 2001) by increasing the number (Kostenuik et al. 1999) or function of osteoblasts (Rubin et al. 2002) and increasing osteoblast life span by inhibiting osteoblast apoptosis, an anabolic effect (Jilka et al. 1999). Continuous infusion of PTH decreases bone mass by stimulating a net increase in bone resorption, a catabolic effect (Lee \& Lorenzo 1999, Ma et al. 2001). Recent studies indicate that the anabolic action of PTH on bone is site specific (Halloran et al. 1997, Iida-Klein et al. 2002). Some factors, such as insulin-like growth factor I (IGF-I), are required for the anabolic actions of PTH on bone (Bikle et al. 2002). The responses of bone to PTH are also dose- (Frolik et al. 1999) and time-dependent (Ishizuya et al. 1997, Schiller et al. 1999), and vary among species and strains (Hock 2000).
In some of our previous experiments, we observed a gender difference regarding the response of bone to PTH in bone mass in mice, but no detailed reports have been published on this observation to our knowledge. Because of the increasing use of genetically altered mice and the extrapolation of such studies to human physiology and pathophysiology, we undertook the current study.

Gender has been found to exert effects on skeletal development (Naganathan et al. 2002), peak bone mass (Orwoll et al. 2001), and peak appendicular bone strength (Kim et al. 2003) in human, mice and rats. These effects have been attributed to sex steroid action (Turner 1999, Zhang et al. 1999) or genetic (Eisman 1999, Orwoll et al. 2001) mechanisms. Recent clinical studies also indicate that gender affects the bone response to growth hormone (Johansson et al. 1999, Span et al. 2000), suggesting that gender may affect the bone response to other hormones.

To determine whether the response of mouse bone to PTH differed according to gender, we determined the bone response to PTH at the tissue level, cellular level and 
molecular level by assessing fat free weight (FFW), structure by micro computed tomography $(\mu \mathrm{CT})$, bone histomorphometry, colony forming units in bone marrow stromal cell (BMSC) cultures, and mRNA levels of resorption and formation markers using quantitative real-time PCR.

\section{Materials and Methods}

\section{Animals}

16 week old male and female CD-1 mice were treated with either PTH (PTH 1-34, rat, Bachem, CA, USA) $80 \mu \mathrm{g} / \mathrm{kg}$ body weight (BW) or vehicle everyday by s.c. injection for 2 weeks. To determine bone formation during the period of PTH administration, the mice were injected s.c. with calcein on day 0 of PTH administration followed in 12 days by demeclocycline (each $15 \mathrm{mg} / \mathrm{kg}$ ) to label the mineralization fronts of the bone. Two days later, the mice were weighed and then sacrificed. The right tibias were obtained for fat-free weight and micro computed tomography $(\mu \mathrm{CT})$; the left tibias were obtained for mineral appositional rate (MAR) and bone formation rate (BFR). To determine the effect of PTH on bone marrow stromal cell differentiation and mRNA levels of bone markers, the mice were sacrificed $1 \mathrm{~h}$ after the last PTH treatment. Left tibias and femurs were obtained for mRNA determinations. BMSC from right tibias and femurs were collected individually for cell culture. These studies were approved by the Animal Use Committee of the San Francisco Veterans Affairs Medical Center where the animals were raised and studied.

\section{Bone fat-free weight}

The tibias were cleaned of adherent tissue, extracted in ethanol and diethyl ether using a soxhlet apparatus (Fisher Scientific, Pittsburgh, PA, USA), then dried at $100{ }^{\circ} \mathrm{C}$ overnight and weighed.

\section{$\mu C T$}

The tibias were analyzed with a Scanco Medical AG $\mu \mathrm{CT}$ apparatus (Scanco Medical AG, Basserdorf, Switzerland) as previously described (Bikle et al. 2001, 2002, von Stechow et al. 2004). Three-dimensional (3D) information was obtained by stacking successively measured slices on top of each other. The voxel size was $9 \mu \mathrm{m}$ in all three spatial dimensions. One hundred and twenty-eight slices were measured in each sample, covering a total of $1.15 \mathrm{~mm}$ of the metaphysis. To analyze only cancellous fractions of the tibias, the compact part of the bone was masked out with a 3D box-shaped low-pass filter, applied to the original gray-scale CT images. An artificial partial volume effect was created, which blurs out the individual trabeculae but leaves the dense compact shell intact. The cortex mask was then extracted with a simple thresholding operation with a fixed threshold of $20 \cdot 0 \%$ of the maximal gray-scale value. To analyze the cortex, a low-pass Gaussian filter $(s=3 \cdot 0)$ was applied to the original images, with a threshold of $10 \cdot 0 \%$. The axial position and extent are identical with the trabecular volume. The trabecular region was masked out, and a $3 \mathrm{D}$ component labeling of the cortex was performed additionally to extract only the main connected component. Then, the cortex was evaluated with the direct distance transformation method to calculate its thickness. Bone volume (BV) and bone surface (BS) were calculated using a tetrahedron meshing technique generated with the marching cubes method. Total volume (TV) was calculated from the volume of the conforming voxels of interest.

\section{Bone histomorphometry}

MAR and BFR at the tibiofibular junction (TFJ) were measured as follows. Diaphyseal segments of the tibias were dehydrated, defatted in acetone followed by ether, and then embedded in bioplastic (Tap Plastics, Dublin, CA, USA). After polymerizing overnight, the blocks were sectioned at a thickness of $60 \mu \mathrm{m}$ using a Leica SP 1600 circular bone saw (Leica Inc, Deerfield, IL, USA). The section containing the TFJ was digitized with a Hamamatsu video camera (Carl Zeiss Inc, Thornwood, NY, USA) coupled to a Leica DMR microscope, and periosteal MAR, BFR, single labeling surface of endosteal surface, cortical bone area and medullary area were determined using the National Institutes of Health (NIH) Image program.

\section{BMSC culture}

The left tibial and femoral bone marrow stromal cells were harvested using techniques previously described (Kostenuik et al. 1999). Briefly, the tibias and femurs were collected and the soft tissue was removed, followed by a brief immersion in $70 \%$ ethanol. The epiphyses of each bone were removed, and the bone marrow was flushed from the diaphysis with a syringe and a 26 gauge needle. The marrow from each individual mouse was collected in primary culture medium (alpha modification of Eagle's medium $[\alpha-M E M]$ containing L-glutamine and nucleosides; Mediatech, Herndon, VA, USA), supplemented with 10\% fetal bovine serum (FBS; Atlanta Biologicals, Norcross, GA, USA), $100 \mathrm{U} / \mathrm{ml}$ penicillin/streptomycin (Mediatech), $0 \cdot 25 \mu \mathrm{g} / \mathrm{ml}$ fungizone (Life Technologies). A single-cell suspension was obtained by repeated passage through an 18 gauge needle. A pool of BMSCs was made from the tibia and femur of each mouse. The cells were plated at $2 \times 10^{6}$ cells/well in 6-well plates. Nonadherent cells were removed by aspiration, and then the 
Table 1 Primers and probes for real-time PCR

\begin{tabular}{|c|c|c|c|}
\hline & Primer and probe & Sequence $\left(5^{\prime}-3^{\prime}\right)$ & $\begin{array}{l}\text { PCR products } \\
\text { (bp) }\end{array}$ \\
\hline \multicolumn{4}{|l|}{ Gene } \\
\hline \multirow[t]{3}{*}{ GAPDH } & Forward primer & TGCACCACCAACTGCTTAG & \multirow[t]{3}{*}{177} \\
\hline & Reverse primer & GGATGCAGGGATGATGTTC & \\
\hline & Probe & aCAGAAGACTGTGGATGGCСССТCb & \\
\hline \multirow[t]{3}{*}{ IGF-1 } & Forward primer & TTCAGTTCGTGTGTGGACCG & \multirow[t]{3}{*}{112} \\
\hline & Reverse primer & GCTCCGGAAGCAACACTCAT & \\
\hline & Probe & aCTTTTACTTCAACAAGCCCACAGGCTATGGb & \\
\hline \multirow[t]{3}{*}{ IGF-1R } & Forward primer & CACGACGATGAGTGCATGC & \multirow[t]{3}{*}{151} \\
\hline & Reverse primer & GAGCAGAAGTCACCGAATCGA & \\
\hline & Probe & aATCCССТGCGAAGGCСССТGb & \\
\hline \multirow[t]{3}{*}{ RANKL } & Forward primer & GGCCACAGCGCTTCTCAG & \multirow[t]{3}{*}{144} \\
\hline & Reverse primer & GAGTGACTTTATGGGAACCCGAT & \\
\hline & Probe & aCAGCTATGATGGAAGGCTCATGGTTGGAb & \\
\hline \multirow[t]{3}{*}{ OPG } & Forward primer & AGTCCGTGAAGCAGGAGTG & \multirow[t]{3}{*}{172} \\
\hline & Reverse primer & CCATCTGGACATTTTTTGCAAA & \\
\hline & Probe & aTGCAAGCTGGAACCCCAGAGCCb & \\
\hline
\end{tabular}

a, $5^{\prime}$ end labeled with the reporter dye FAM; b, $3^{\prime}$ end labeled with the quencher dye TAMRA.

primary medium was replenished on day 5 . On day 7 , the cells were provided with secondary medium (the primary medium with $3 \mathrm{mM} \beta-$ glycerophosphate and $50 \mu \mathrm{g} / \mathrm{ml}$ ascorbic acid; Sigma). Subsequent medium changes were performed every 2 days for up to 28 days.

\section{Alkaline phosphatase (ALP) assay}

On day 14, cells were fixed with 10\% phosphate-buffered formalin for $30 \mathrm{~min}$ for determining ALP activity and colony number. To determine ALP activity, the fixed cells were rinsed with distilled water, and then incubated for 30 min at $37^{\circ} \mathrm{C}$ with a solution containing equal parts p-nitrophenol phosphate (Sigma) and alkaline buffer solution (Sigma). After the incubation, the reaction was stopped with equivolume $0 \cdot 1 \mathrm{M} \mathrm{NaOH}$. The absorbance (arbitrary units) was measured with a Uvikon spectrophotometer 930 (Research Instruments, San Diego, CA, USA) at $410 \mathrm{~nm}$. To determine the number of colony forming units, the same cultures were rinsed with distilled water, and then stained with a $0 \cdot 2 \%$ crystal violet (Sigma) in 2\% ethanol for $1 \mathrm{~h}$ at room temperature. The staining solution was aspirated, and unbound stain was removed by rinsing the cultures 4 times with distilled water. The number of colonies over $1 \mathrm{~mm}$ in diameter was recorded. The crystal violet solution was eluted with 0.2\% Triton X-100 (Sigma), and the absorbance was measured with a spectrophotometer at $590 \mathrm{~nm}$ for the determination of cell number as previously described (Kostenuik et al. 1999).

\section{$m R N A$ levels in bone}

The right femurs and tibias were cleaned of adherent tissue, the marrow flushed out with PBS using a 26 gauge needle, and the bones frozen in liquid nitrogen and stored at $-80^{\circ} \mathrm{C}$ until processed. The bones from each animal were pooled, and bone pools were pulverized in a steel mortar and pestle cooled in liquid nitrogen. RNAs were isolated by a RNA Stat-60 kit (Tel-Test, Friendswood, TX, USA). For each pool $2000 \mathrm{ng}$ of total RNA was reverse-transcribed in $100 \mu \mathrm{l}$ of a reaction mixture that contained $10 \mathrm{mM}$ Tris- $\mathrm{HCl}(\mathrm{pH} \quad 8 \cdot 3), 50 \mathrm{mM} \mathrm{KCl}$, $7.5 \mathrm{mM} \mathrm{MgCl} 2,1 \mathrm{mM}$ of each deoxynucleoside triphosphate, $5 \mu \mathrm{M}$ of random primers (GIBCO BRL), $0 \cdot 4 \mathrm{U} / \mu \mathrm{l}$ of RNAse inhibitor (Roche), and 2.5 $\mathrm{U} / \mu \mathrm{l}$ of Moloney murine leukemia virus reverse transcriptase (GIBCO $\mathrm{BRL}$ ) at $25^{\circ} \mathrm{C}$ for $10 \mathrm{~min}, 48{ }^{\circ} \mathrm{C}$ for $40 \mathrm{~min}, 95^{\circ} \mathrm{C} 5 \mathrm{~min}$, and then stored at $4{ }^{\circ} \mathrm{C}$. The sequences of the PCR primers and probes are listed in table 1 . These primers and probes were designed using Primer Express software (Applied Biosystems, Foster City, CA, USA). Primers were synthesized by the Biomolecular Resource Center (University of California, San Francisco, CA, USA). Probes were synthesized by Integrated DNA Technologies, Inc (Coralville, IA, USA). The internal probe was labeled at the 5 'end (labeled as ' $a$ ' in table 1) with the reporter dye 6-carboxyfluorescein (FAM) and at the $3^{\prime}$ end (labeled as ' $b$ ' in table 1) with quencher dye 6-carboxy-tetramethylrhodmine. During PCR, the $5^{\prime}-3^{\prime}$ nuclease activity of Taq DNA polymerase releases the reporter fluorescence (Heid et al. 1996). The fluorescence intensity is proportional to the accumulation of PCR product and was detected with an ABI Prism 7900HT sequence detection system (Applied Biosystems, Branchburg, NJ, USA). The sequence of the probe or primers for each target gene spans an exon/exon boundary to minimize the signal generated by genomic DNA that may contaminate the RNA sample, thereby eliminating the need to DNAse treat the sample. 
PCR was carried out in triplicate with $20-\mu$ l reaction volumes of 1X TaqMan Universal PCR Master Mix, (Applied Biosystems), $500 \mathrm{nM}$ of each primer, $200 \mathrm{nM}$ of probe and $1 \mu \mathrm{l}$ of $\mathrm{cDNA}$ template. The PCR reaction was performed in an ABI Prism 7900HT sequence detection system using the following cycles: $95{ }^{\circ} \mathrm{C}$ for $12 \mathrm{~min}$, then 40 cycles of $95{ }^{\circ} \mathrm{C}$ for $15 \mathrm{~s}$ and $60{ }^{\circ} \mathrm{C}$ for 1 minute. Analysis was carried out using the sequence detection software supplied with the ABI Prism 7900HT sequence detection system. The number of PCR cycles, threshold cycles (Ct), required for the FAM intensities to exceed a threshold above background was calculated for the test reactions (Ginzinger et al. 2000). The Ct values were determined for three test reactions in each sample and averaged. The $\Delta \mathrm{Ct}$ values were obtained by subtracting the GAPDH (as endogenous control) Ct values from the target gene $\mathrm{Ct}$ values of the same samples. The relative quantification of the target genes was given by $2^{-\Delta \mathrm{Ct}}$.

\section{Statistical analysis}

Data are presented as mean \pm S.D All data were analyzed using two-factor (gender and treatment) ANOVA followed by a post-hoc Fisher's protected least significant difference test with a SuperANOVA program. Statistical significance was taken as $P<0 \cdot 05$.

\section{Results}

\section{Bone mass}

The fat-free weights of tibias (normalized by body weight, FFW/BW) are shown in Fig. 1. By one-way ANOVA analysis, in control mice, FFW/BW of females $(1.23$ $\pm 0.12 \mathrm{mg} / \mathrm{g}$ ) was significantly greater than $\mathrm{FFW} / \mathrm{BW}$ of males $(0.89 \pm 0.15 \mathrm{mg} / \mathrm{g} ; \quad P<0.05)$. PTH significantly increased $\mathrm{FFW} / \mathrm{BW}$ by $30 \%$ in male mice $(1.18$ $\pm 0.19 \mathrm{mg} / \mathrm{g} ; \quad P<0.05)$, but induced no significant changes in female mice $(1 \cdot 16 \pm 0 \cdot 21 \mathrm{mg} / \mathrm{g})$. Two-way ANOVA revealed a significant PTH treatment-gender interaction $(\mathrm{F}=7 \cdot 802 ; P=0 \cdot 0099)$.

\section{Bone structure-proximal tibia}

$\mu \mathrm{CT}$ was used to evaluate the gender differences in bone structure. The results are shown in Table. 2. In control male mice, cortical bone thickness and mean trabecular separation were significantly less (87 and $71 \%$ of females, respectively), while $\mathrm{TV}, \mathrm{BV}, \mathrm{BV} / \mathrm{TV}$, connectivity density and mean trabecular number were significantly greater $(138,189,133$, and $237 \%$ of females). PTH significantly decreased BV (30\%) in male mice compared with the control, but induced no significant changes in female mice although the trend was comparable. PTH had no significant

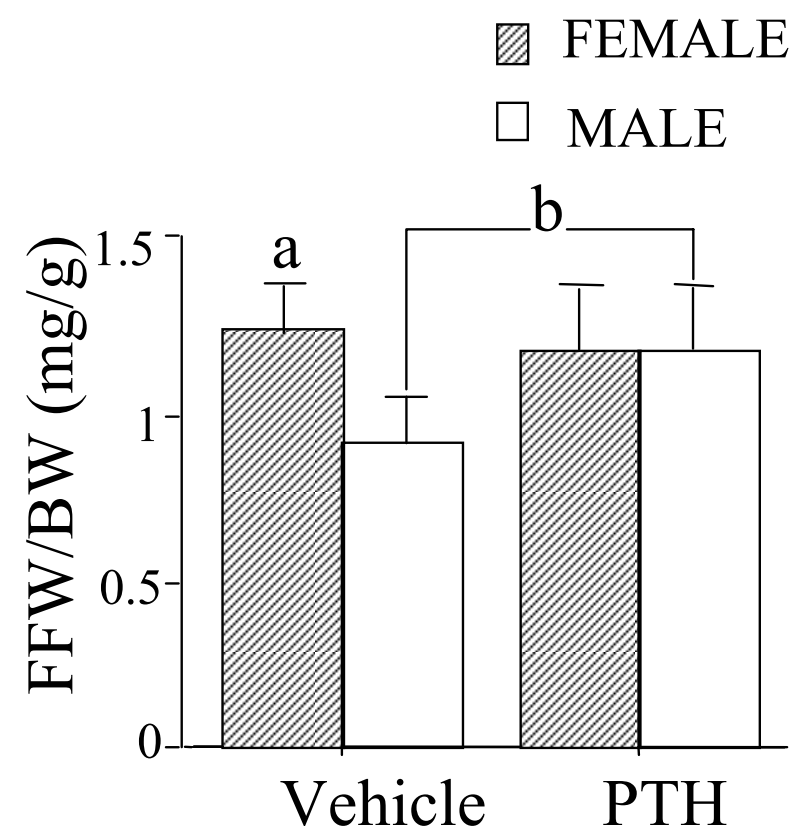

Figure 1 Gender differences in the response of FFW/BW of tibia to PTH. Results are expressed as mean \pm S.D. There were nine females and seven males in the vehicle group, and eight females and six males in the PTH-treated group. $a, P<0.05$ female control vs male control; $b, P<0.05$ control vs PTH treatment.

effect on connectivity density or proximal cortical thickness in either gender.

\section{Bone formation: TFJ}

We determined gender differences in bone formation by bone histomorphometry at the TFJs. The results are shown in Fig. 2. PTH treatment significantly increased periosteal BFR (Fig. 2A), MAR (Fig. 2B) and endosteal sLS/BS (Fig. 2C) (60, 44, 40, respectively, $P<0 \cdot 05)$, decreased medullary area (Fig. 2D) $(39 \%, P<0.05)$ at the TFJ in male mice, but induced no significant changes in female mice although the trends were comparable. Two-way ANOVA analysis showed significant interactions between PTH effects and gender on these measurements $(P=0 \cdot 05, P=0 \cdot 05, P=0 \cdot 04$, and $P=0 \cdot 03$, respectively). The increase in cortical bone area in male mice with PTH treatment (Fig. 2E, 13\%) did not reach statistical significance.

\section{BMSC differentiation}

We analyzed bone marrow stromal cell differentiation by examining both colony number and ALP activity. On day 14 of cell culture, colony number and ALP activity tended to be greater in BMSC from male mice than from female mice (Fig 3), although these differences were not statistically significant. PTH given in vivo increased colony number 
Table 2 Gender differences in bone structure

\begin{tabular}{|c|c|c|c|c|c|c|c|c|}
\hline & TV & BV & $\mathrm{BV} / \mathrm{TV}$ & Conn-Dens & C.Th & Tb.N & Tb.Th & Tb.Sp \\
\hline Vehicle (F) & $1 \cdot 3 \pm 0 \cdot 2$ & $0 \cdot 19 \pm 0 \cdot 05$ & $0 \cdot 15 \pm 0 \cdot 03$ & $67 \cdot 4 \pm 51 \cdot 1$ & $0 \cdot 15 \pm 0 \cdot 01$ & $4 \cdot 3 \pm 0 \cdot 8$ & $0.053 \pm 0.010$ & $0 \cdot 24 \pm 0.05$ \\
\hline Vehicle (M) & $1 \cdot 8 \pm 0 \cdot 1^{\mathrm{a}}$ & $0 \cdot 36 \pm 0 \cdot 13^{a}$ & $0 \cdot 20 \pm 0 \cdot 07^{a}$ & $159 \cdot 4 \pm 88 \cdot 5^{a}$ & $0 \cdot 13 \pm 0.01^{a}$ & $5 \cdot 8 \pm 0 \cdot 9^{a}$ & $0.048 \pm 0.009$ & $0 \cdot 17 \pm 0.03^{a}$ \\
\hline PTH (F) & $1 \cdot 2 \pm 0 \cdot 1$ & $0 \cdot 13 \pm 0 \cdot 07$ & $0 \cdot 11 \pm 0 \cdot 05$ & $70 \cdot 9 \pm 53 \cdot 2$ & $0 \cdot 14 \pm 0 \cdot 02$ & $3.9 \pm 0.9$ & $0 \cdot 048 \pm 0.012$ & $0 \cdot 28 \pm 0 \cdot 08$ \\
\hline PTH (M) & $1 \cdot 7 \pm 0 \cdot 4$ & $0 \cdot 27 \pm 0.06^{b}$ & $0 \cdot 16 \pm 0 \cdot 05$ & $96 \cdot 2 \pm 43 \cdot 1$ & $0 \cdot 14 \pm 0.03$ & $5 \cdot 1 \pm 0 \cdot 9$ & $0.049 \pm 0.007$ & $0.17 \pm 0.03$ \\
\hline
\end{tabular}

Results are expressed as mean \pm S.D. ${ }^{a} P<0.05$ female control vs male control; ${ }^{b} P<0.05$ control vs PTH treatment; $F$, female; $M$, Male; TV, total bone volume $\left(\mathrm{mm}^{3}\right)$; BV, bone volume $\left(\mathrm{mm}^{3}\right)$; Conn-Dens, connectivity density $\left(\mathrm{l} / \mathrm{mm}^{3}\right)$; C.Th, cortical bone thickness $(\mathrm{mm}) ; \mathrm{Tb} . \mathrm{N}$, mean trabecular number $(\mathrm{l} / \mathrm{mm}) ; \mathrm{Tb} . T \mathrm{~h}$, mean trabecular thickness $(\mu \mathrm{m}) ;$ Tb.Sp, mean trabecular separation $(\mu \mathrm{m})$.

and ALP activity in BMSC from both female mice $(2 \cdot 5-$ and $4 \cdot 0$-fold, respectively) and male mice $(1 \cdot 5-$ and 2.5-fold, respectively). Two-way ANOVA showed significant PTH-gender interaction on ALP activity, but not on colony number.

\section{$m R N A$ levels of bone markers}

mRNA levels of bone markers were determined by quantitative real-time PCR. The results are shown in Fig 4 and 5. These values are expressed as a percentage of the female controls. All values have been normalized to GAPDH mRNA levels in the same samples. PTH significantly increased the mRNA levels of IGF-1 (Fig.4A) and IGF-1 receptor (IGF-1R, Fig. 4B) in male mice (605, $320 \%$ respectively), but not in female mice. The interactions between PTH effects and gender were significant $(P=0 \cdot 01, P=0 \cdot 02$, respectively, by two way ANOVA). Basal levels of IGF-1 mRNA were lower in male mice, however. PTH increased the mRNA levels of receptor activator of nuclear factor $\kappa \mathrm{B}$ ligand (RANKL) (Fig.5 A) in both male (14-fold) and female (16-fold) mice, but it did not alter osteoprotegerin (OPG) mRNA levels at least at this time point (1 h after last PTH treatment) (Fig. $5 \mathrm{~B}$ ).

\section{Discussion}

In this mouse strain, females had greater tibial bone mass as a proportion of body weight as indicated by FFW/BW and cortical thickness of the proximal tibia. However, males had more trabecular bone as indicated by higher $\mathrm{TV}, \mathrm{BV}, \mathrm{BV} / \mathrm{TV}$, mean trabecular number and less mean trabecular separation in the proximal tibia. The thicker cortex in females may be the result of greater endocortical expansion. These results are consistent with Kim and coworker's observations in rats (Kim et al. 2003). These gender differences in bone mass and structure have been assumed to exist based on sex steroid action (Orwoll et al. 2001) but less studies have been carried out. Somjen et al. (1994) reported that the skeletal response to sex hormones is gender-specific. Cell proliferation in the rat diaphysis is stimulated only by estrogens in females and only by androgens in males. Androgen is growth promoting; it stimulates periosteal bone formation in males, while estrogen is growth limiting and accounts for the cessation of longitudinal growth and periosteal expansion in females (Zhang et al. 1999). Orwoll et al. (2001) also reported that the marked gender differences in peak bone size/mass were, in part, associated with quantitative trait loci, suggesting the effects of genetic influences on gender differences in bone.

In our study, gender also exerts a profound effect on the skeletal response to $\mathrm{PTH}$ on bone mass and structure. PTH significantly increased FFW/BW, which represents total bone mass (including cortical bone and trabecular bone), in male mice, but not in female mice, indicating that PTH has a greater overall anabolic effect on bone in males than in females. Furthermore, histomorphometric analysis showed that PTH increased cortical bone parameters, including periosteal BFR and MAR, endosteal sLS/BS, and decreased medullary area in male mice, but not in female mice, while reducing trabecular bone volume. Thus the overall increase in bone mass in male mice following PTH is primarily due to an increase in cortical bone, consistent with earlier studies (Parfitt 2002).

At the cellular level, we analyzed the effects of PTH given in vivo on bone marrow stromal cell (BMSC) proliferation and differentiation in vitro. We found that PTH increased colony number and ALP activity in both male and female mice. These results are consistent with previous observations that PTH promotes bone marrow stromal cell precursor differentiation (Nishida et al. 1994, Ishizuya et al. 1997, Locklin et al. 2003), increasing osteoblast number (Sabatini et al. 1996) or their functional activities (Schiller et al. 1999). The increase in colony number and ALP activity was greater in female mice $(2 \cdot 5-$, $4 \cdot 0$-fold, respectively) than in male mice $(1 \cdot 5-$ and $2 \cdot 5$ fold, respectively). However, male mice in the absence of PTH tended to have more osteoprogenitor cells and higher ALP activities than female mice, and this difference persisted following PTH administration. In a previous study, Nasu et al.(2000) demonstrated that PTH stimulated osteoblast function such as ALP activity and collagen synthesis following pretreatment with estrogen, but it did not affect osteoblast function in the absence of estrogen 

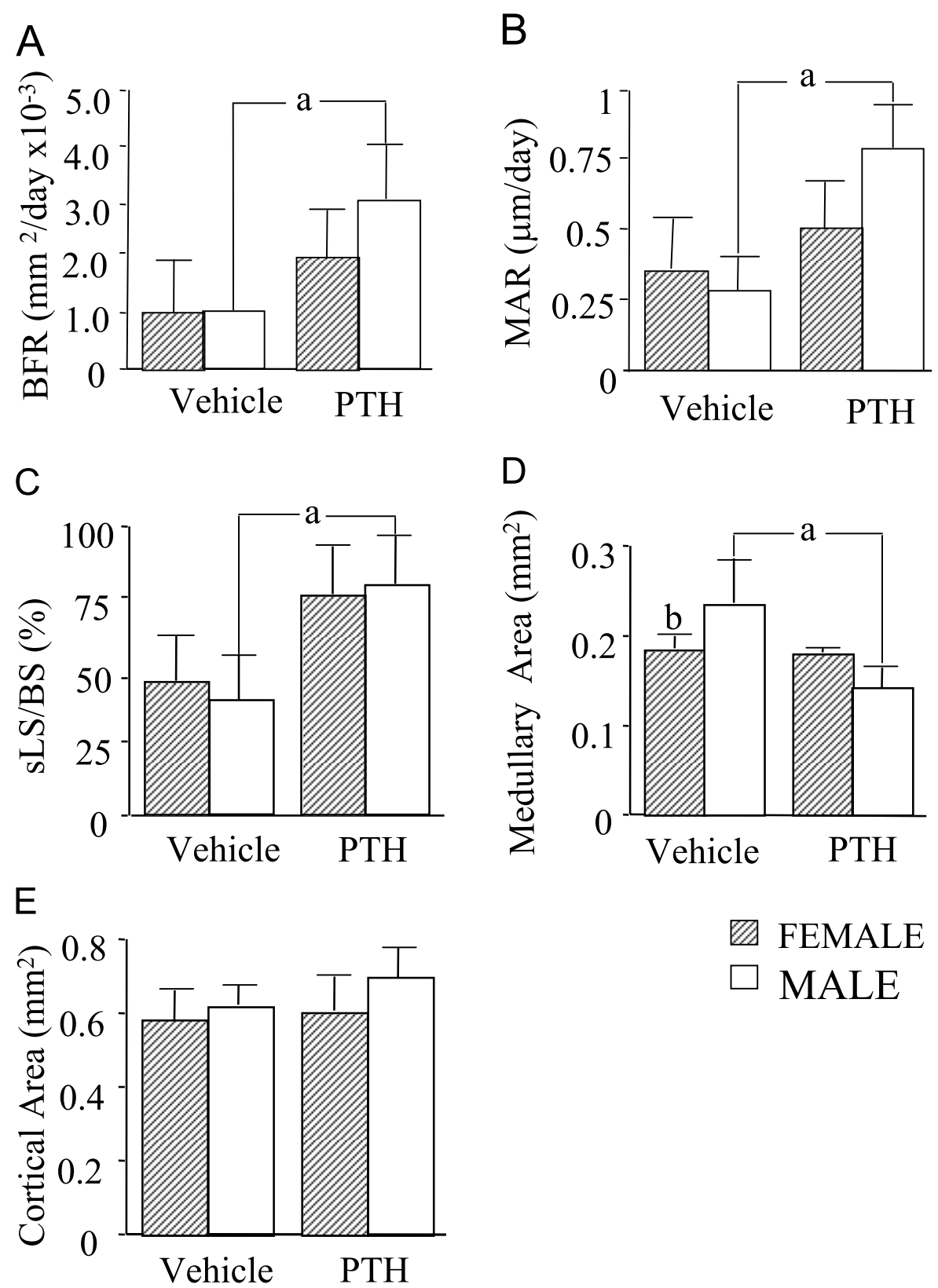

Figure 2 Gender differences in periosteal and endosteal bone formation at the tibiofibular junction as assessed by bone histomorphometry. Results are expressed as mean \pm S.D. (A) Periosteal bone formation rate (BFR/BS). (B) Mineral apposition rate (MAR). (C) Endosteal single labeling surface (sLS/BS). (D) Medullary area. (E) Cortical bone area. There are nine females, five males in the vehicle group, and six females, five males in the PTH-treated group. a, $P<0 \cdot 05$ PTH treatment vs control; $b, P<0 \cdot 05$ female control vs male control.

pretreatment, suggesting that estrogen plays an important role in the anabolic effects of PTH on osteoblast differentiation. This suggests that the gender difference in the anabolic effects of PTH on BMSC is at least partly based on estrogen action. The gender differences in our studies are ones of degree, not significance. Conceivably, such differences could be exaggerated or eliminated in longer term studies.

In this study, we used quantitative real-time PCR to analyze gender differences in the bone response to PTH at 

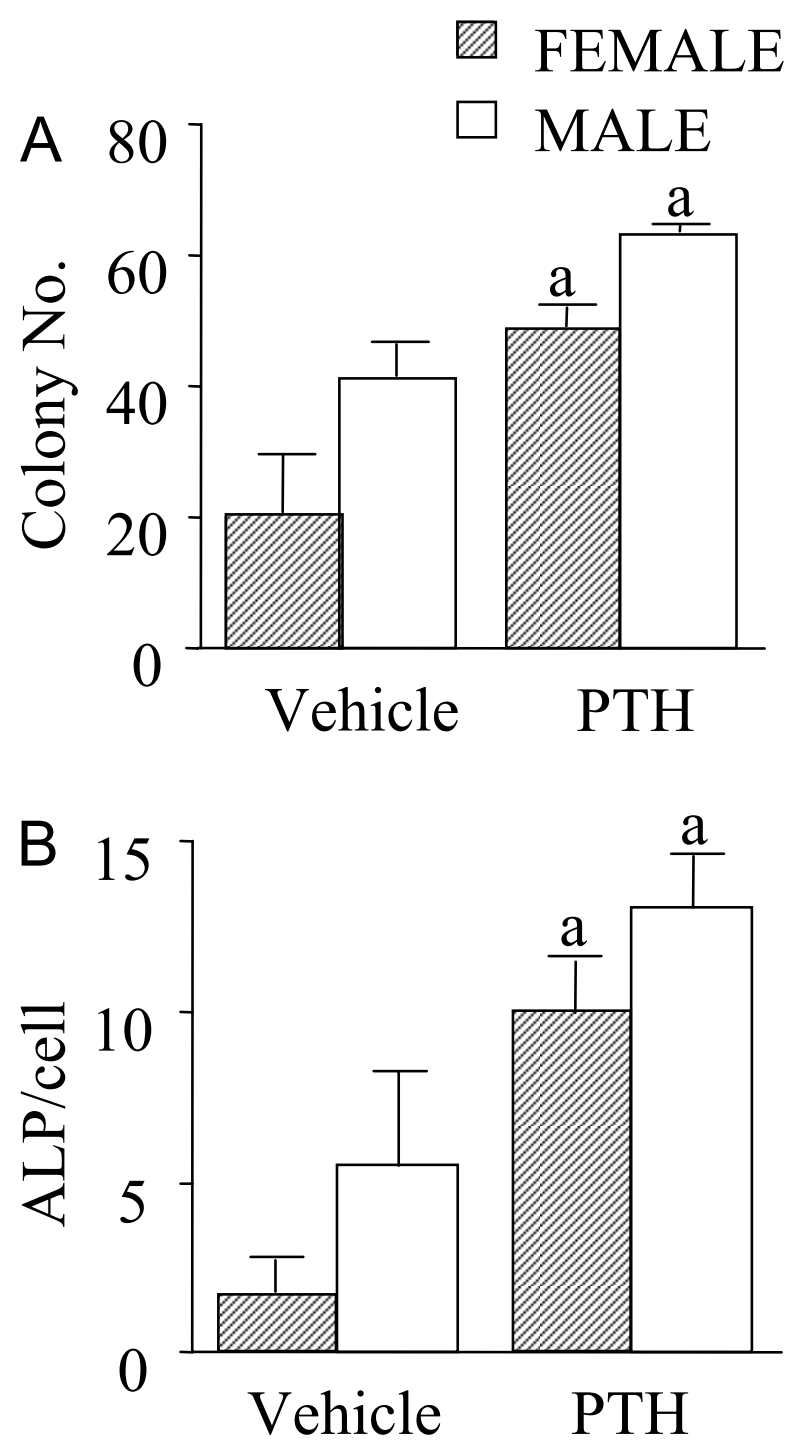

Figure 3 Gender differences in BMSC colony number and ALP activity (Day 14). Results are expressed as mean \pm S.D. (A) Colony number and (B) ALP activity (ALP/cell). $n=3$ in each group. a, $P<0.05$ PTH treatment vs control.

the molecular level. In a pilot study (data not shown), we treated CD-1 mice with $80 \mu \mathrm{g}$ PTH/kg per day or vehicle for 2 weeks, and sacrificed the mice at $0,1,3,6,12$ and $24 \mathrm{~h}$ after the last PTH injection. This study showed that the greatest effects of PTH on RANKL (a stimulator of osteoclastogenesis) expression occurred $1 \mathrm{~h}$ after the last PTH injection, whereas OPG (a decoy receptor for RANKL) was stimulated maximally at $6 \mathrm{~h}$. In this study, we collected our samples $1 \mathrm{~h}$ after the last PTH injection. Our results showed that PTH significantly stimulated gene expression of RANKL in male and female mice, consistent with other studies (Iida-Klein et al. 2002). The increases
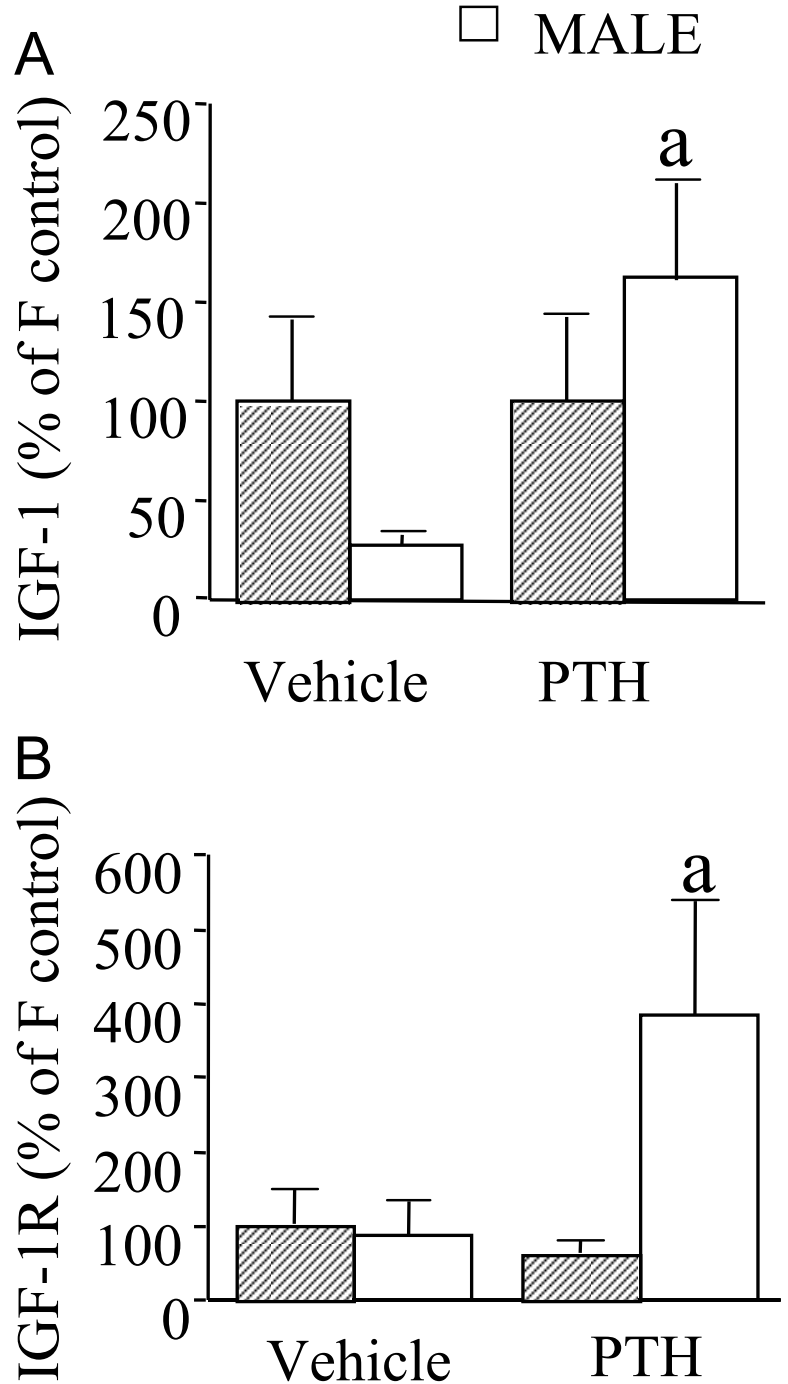

Figure 4 Gender differences in the response to PTH with respect to mRNA levels of bone formation markers. (A) IGF-1 and (B) IGF-1R. Results are expressed as percentage of female control, all values have been normalized to GAPDH mRNA levels in the same sample. $n=3$ in each group. a, $P<0.05$ PTH treatment vs control.

in male and female mice were comparable, indicating no gender differences in this response to $\mathrm{PTH}$.

Previous studies indicated that PTH potently stimulates synthesis of IGF-I by osteoblasts, and thus newly synthesized IGF-I may directly increase osteoblast replication and bone formation (McCarthy \& Centrella 2001). Our group (Bikle et al. 2002) has reported that IGF-1 was required for the anabolic effects of PTH on cortical bone. In this study, we found that PTH increased the mRNA levels of IGF-I and its receptor (IGF-IR) only in male mice. Although several reports suggested a stimulatory effect 

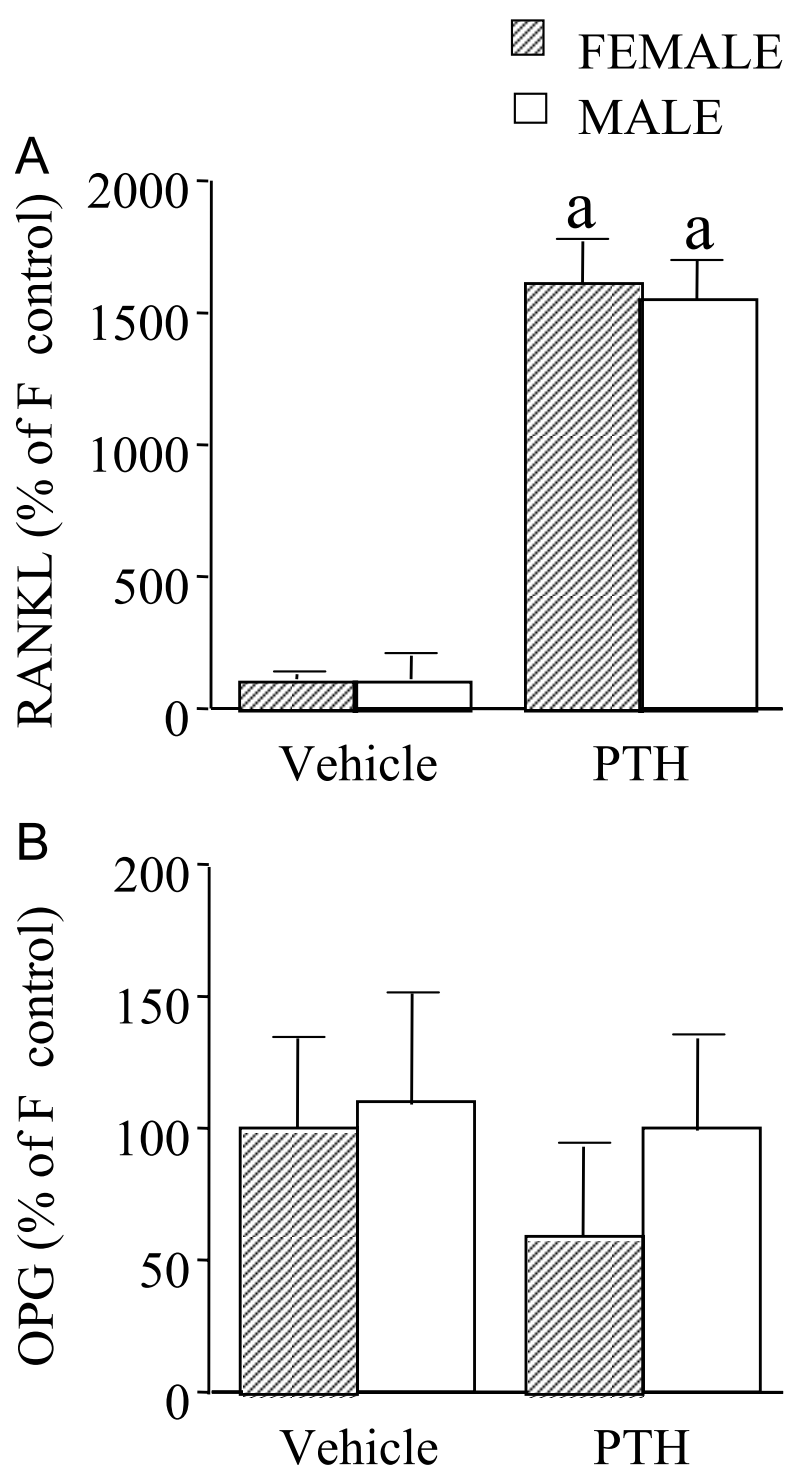

Figure 5 Gender differences in the response to $\mathrm{PTH}$ with respect to mRNA levels of OPG and RANKL. Results are expressed as percentage of female control, and all values have been normalized to GAPDH mRNA levels in the same sample. $n=3$ in each group. a, $P<0.05$ PTH treatment vs control.

by estrogen on IGF-I synthesis by osteoblasts (Watson et al. 1995, Nasu et al. 2000), recent findings indicate that the influence of estrogen on IGF-I gene expression is complex and perhaps indirect (McCarthy et al. 1997). Estrogen is able to diminish IGF-I gene activation by PTH or PGE2 as well as by GH (McCarthy \& Centrella 2001). In this way, it may limit the effects of these hormones on bone formation rates. Thus, the greater response of bone from male mice to $\mathrm{PTH}$ with respect to IGF-I and IGF-IR may account for the greater response of bone from male mice with respect to periosteal bone formation.
In summary, our results indicate that, on balance, in the CD-1 mouse strain, a 2-week course of PTH is anabolic on cortical bone. These effects are modified by gender with male mice showing greater sensitivity to PTH than female mice. These differences may reflect the greater response to PTH of IGF-I and IGF-I receptor gene expression in males, a response which we have previously shown are required for the anabolic effects of PTH in this mouse strain.

\section{Acknowledgments}

This work was supported by grant NIH RO1 DK 5493. The authors declare that there is no conflict of interest that would prejudice the impartiality of this scientific work.

\section{References}

Alexander JM, Bab I, Fish S, Muller R, Uchiyama T, Gronowicz G, Nahounou M, Zhao Q, White DW, Chorev M et al. 2001 Human parathyroid hormone 1-34 reverses bone loss in ovariectomized mice. Journal of Bone and Mineral Research 16 1665-1673.

Bikle D, Majumdar S, Laib A, Powell-Braxton L, Rosen C, Beamer W, Nauman E, Leary C \& Halloran B 2001 The skeletal structure of insulin-like growth factor I-deficient mice. Journal of Bone and Mineral Research 16 2320-2329.

Bikle DD, Sakata T, Leary C, Elalieh H, Ginzinger D, Rosen CJ, Beamer W, Majumdar S \& Halloran BP 2002 Insulin-like growth factor I is required for the anabolic actions of parathyroid hormone on mouse bone. Journal of Bone and Mineral Research 17 1570-1578.

Dempster DW, Cosman F, Kurland ES, Zhou H, Nieves J, Woelfert L, Shane E, Plavetic K, Muller R, Bilezikian J et al. 2001 Effects of daily treatment with parathyroid hormone on bone microarchitecture and turnover in patients with osteoporosis: a paire d biopsy study. Journal of Bone and Mineral Research 16 1846-1853.

Eisman JA 1999 Genetics of osteoporosis. Endocrine Reviews 20 788-804.

Frolik CA, Cain RL, Sato M, Harvey AK, Chandrasekhar S, Black EC, Tashjian AH Jr. \& Hock JM 1999 Comparison of recombinant human PTH(1-34) (LY333334) with a C-terminally substituted analog of human PTH-related protein(1-34) (RS-66271): In vitro activity and in vivo pharmacological effects in rats. Journal of Bone and Mineral Research 14 163-172

Ginzinger DG, Godfrey TE, Nigro J, Moore DH, Suzuki S, Pallavicini MG, Gray JW \& Jensen RH 2000 Measurement of DNA copy number at microsatellite loci using quantitative PCR analysis. Cancer Research 60 5405-5409.

Halloran BP, Bikle DD, Harris J, Tanner S, Curren T \& Morey-Holton E 1997 Regional responsiveness of the tibia to intermittent administration of parathyroid hormone as affected by skeletal unloading. Journal of Bone and Mineral Research 12 1068-1074.

Heid C A, Stevens J, Livak KJ \& Williams PM 1996 Real time quantitative PCR. Genome Research 6 986-994.

Hock JM 2000 Discrimination among osteoblasts? Parathyroid hormone analog may reveal site-specific differences in mice. Bone 27 467-469.

Iida-Klein A, Zhou H, Lu SS, Levine LR, Ducayen-Knowles M, Dempster DW, Nieves J \& Lindsay R 2002 Anabolic action of parathyroid hormone is skeletal site specific at the tissue and cellular levels in mice. Journal of Bone and Mineral Research 17 808-816. 
Ishizuya T, Yokose S, Hori M, Noda T, Suda T, Yoshiki S \& Yamaguchi A 1997 Parathyroid hormone exerts disparate effects on osteoblast differentiation depending on exposure time in rat osteoblastic cells. Journal of Clinical Investigation 99 2961-2970.

Jilka RL, Weinstein RS, Bellido T, Roberson P, Parfitt AM \& Manolagas SC 1999 Increased bone formation by prevention of osteoblast apoptosis with parathyroid hormone. Journal of Clinical Investigation 104 439-446.

Johansson AG, Engstrom BE, Ljunghall S, Karlsson FA \& Burman P 1999 Gender differences in the effects of long term growth hormone $(\mathrm{GH})$ treatment on bone in adults with $\mathrm{GH}$ deficiency. Journal of Clinical Endocrinology and Metabolism 84 2002-2007.

Kim BT, Mosekilde L, Duan Y, Zhang XZ, Tornvig L, Thomsen JS \& Seeman E 2003 The structural and hormonal basis of sex differences in peak appendicular bone strength in rats. Journal of Bone and Mineral Research 18 150-155.

Kostenuik PJ, Harris J, Halloran BP, Turner RT, Morey-Holton ER \& Bikle DD 1999 Skeletal unloading causes resistance of osteoprogenitor cells to parathyroid hormone and to insulin-like growth factor-I. Journal of Bone and Mineral Research 14 21-31.

Lee SK \& Lorenzo JA 1999 Parathyroid hormone stimulates TRANCE and inhibits osteoprotegerin messenger ribonucleic acid expression in murine bone marrow cultures: correlation with osteoclast-like cell formation. Endocrinology 140 3552-3561.

Locklin RM, Khosla S, Turner RT \& Riggs BL 2003 Mediators of the biphasic responses of bone to intermittent and continuously administered parathyroid hormone. Journal of Cellular Biochemistry 89 180-190.

Ma YL, Cain RL, Halladay DL, Yang X, Zeng Q, Miles RR, Chandrasekhar S, Martin TJ \& Onyia JE 2001 Catabolic effects of continuous human PTH (1-38) in vivo is associated with sustained stimulation of RANKL and inhibition of osteoprotegerin and gene-associated bone formation. Endocrinology 142 4047-4054.

McCarthy TL \& Centrella M 2001 Local IGF-I expression and bone formation. Growth Hormone and IGF Research 11 213-219.

McCarthy T L, Ji C, Shu H, Casinghino S, Crothers K, Rotwein P \& Centrella M 199717 beta-estradiol potently suppresses cAMP-induced insulin-like growth factor-I gene activation in primary rat osteoblast cultures. Journal of Biological Chemistry 272 18132-18139.

Naganathan V, Macgregor A, Snieder H, Nguyen T, Spector T \& Sambrook P 2002 Gender differences in the genetic factors responsible for variation in bone density and ultrasound. Journal of Bone and Mineral Research 17 725-733.

Nasu M, Sugimoto T, Kaji H \& Chihara K 2000 Estrogen modulates osteoblast proliferation and function regulated by parathyroid hormone in osteoblastic SaOS-2 cells: role of insulin-like growth factor (IGF)-I and IGF-binding protein-5. Journal of Endocrinology $167305-313$.
Nishida S, Yamaguchi A, Tanizawa T, Endo N, Mashiba T, Uchiyama Y, Suda T, Yoshiki S \& Takahashi HE 1994 Increased bone formation by intermittent parathyroid hormone administration is due to the stimulation of proliferation and differentiation of osteoprogenitor cells in bone marrow. Bone 15 717-723.

Orwoll ES, Belknap JK \& Klein RF 2001 Gender specificity in the genetic determinants of peak bone mass. Journal of Bone and Mineral Research 16 1962-1971.

Parfitt AM 2002 Parathyroid hormone and periosteal bone expansion. Journal of Bone and Mineral Research 17 1741-1743.

Rubin MR, Cosman F, Lindsay R \& Bilezikian JP 2002 The anabolic effects of parathyroid hormone. Osteoporosis International 13 267-277.

Sabatini M, Lesur C, Pacherie M, Pastoureau P, Kucharczyk N, Fauchere JL \& Bonnet J 1996 Effects of parathyroid hormone and agonists of the adenylyl cyclase and protein kinase $\mathrm{C}$ pathways on bone cell proliferation. Bone 18 59-65.

Schiller PC, D'Ippolito G, Roos BA \& Howard GA 1999 Anabolic or catabolic responses of MC3T3-E1 osteoblastic cells to parathyroid hormone depend on time and duration of treatment. Journal of Bone and Mineral Research 14 1504-1512.

Somjen D, Mor Z \& Kaye AM 1994 Age dependence and modulation by gonadectomy of the sex-specific response of rat diaphyseal bone to gonadal steroids. Endocrinology 134 809-814.

Span JP, Pieters GF, Sweep CG, Hermus AR \& Smals AG 2000 Gender difference in insulin-like growth factor I response to growth hormone $(\mathrm{GH})$ treatment in GH-deficient adults: role of sex hormone replacement. Journal of Clinical Endocrinology and Metabolism 85 1121-1125.

Turner RT 1999 Mice, estrogen, and postmenopausal osteoporosis. Journal of Bone and Mineral Research 14 187-191.

von Stechow D, Zurakowski D, Pettit AR, Muller R, Gronowicz G, Chorev M, Otu H, Libermann T \& Alexander JM 2004 Differential transcriptional effects of PTH and estrogen during anabolic bone formation. Journal of Cellular Biochemistry 93 476-490.

Watson P, Lazowski D, Han V, Fraher L, Steer B \& Hodsman A 1995 Parathyroid hormone restores bone mass and enhances osteoblast insulin-like growth factor I gene expression in ovariectomized rats. Bone 16 357-365.

Zhang XZ, Kalu DN, Erbas B, Hopper JL \& Seeman E 1999 The effects of gonadectomy on bone size, mass, and volumetric density in growing rats are gender-, site-, and growth hormone-specific. Journal of Bone and Mineral Research 14 802-809.

Received in final form 31 January 2006

Accepted 8 February 2006

Made available online as an Accepted Preprint 13 February 2006 